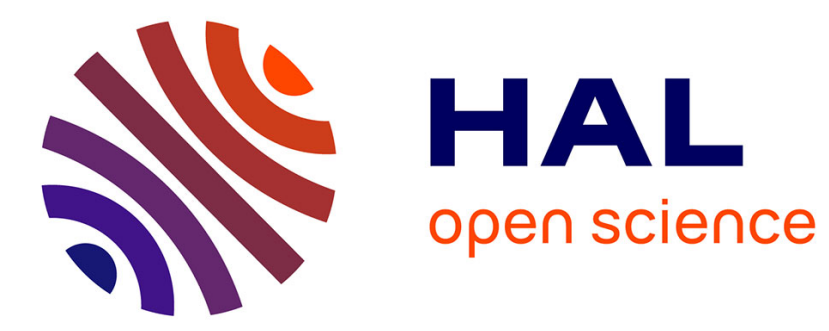

\title{
Long-term effect of cow congregation zone on soil penetrometer resistance: implications for soils and forage quality
}

\author{
Gilbert C. Sigua, Samuel W. Coleman
}

\section{To cite this version:}

Gilbert C. Sigua, Samuel W. Coleman. Long-term effect of cow congregation zone on soil penetrometer resistance: implications for soils and forage quality. Agronomy for Sustainable Development, 2009, 29 (4), 10.1051/agro/2009021 . hal-00886504

\section{HAL Id: hal-00886504 https://hal.science/hal-00886504}

Submitted on 1 Jan 2009

HAL is a multi-disciplinary open access archive for the deposit and dissemination of scientific research documents, whether they are published or not. The documents may come from teaching and research institutions in France or abroad, or from public or private research centers.
L'archive ouverte pluridisciplinaire HAL, est destinée au dépôt et à la diffusion de documents scientifiques de niveau recherche, publiés ou non, émanant des établissements d'enseignement et de recherche français ou étrangers, des laboratoires publics ou privés. 


\title{
Long-term effect of cow congregation zone on soil penetrometer resistance: implications for soils and forage quality
}

\author{
Gilbert C. SiguA*, Samuel W. ColemaN \\ United States Department of Agriculture, Agricultural Research Service, Subtropical Agricultural Research Station, Brooksville, FL, 34601, USA
}

(Accepted 19 May 2009)

\begin{abstract}
Higher degree of soil penetrometer resistance can reduce forage yields and can lead to water and soil quality degradation due to increased runoff and soil structure destruction. The inability of roots to penetrate in soils with high penetrometer resistance will result in decreased yield. With less root penetration into the soil, root mass is reduced and plant's ability to take up nutrients is reduced. To test whether cattle congregation sites typical on most forage-based cow-calf ranches, such as mineral feeders, water troughs, and shaded areas are more compacted and have greater soil penetrometer resistance than in other pasture locations under Florida conditions, soil penetrometer resistance data around and beneath three cattle congregation sites in established ( $>10$ yr) grazed beef cattle pastures were collected in 2004 , 2005 and 2006. Penetrometer readings were collected from two soil depths $(0-20$ and $20-40 \mathrm{~cm})$ at different locations around the cattle congregation sites following radial (every 90 degrees: north, south, east, and west direction) sampling patterns at 0.9, 1.7, 3.3, 6.7, 13.3, 26.7 and 53.3 m away from the approximate center of cattle congregation sites. Results showed that area around or near cattle congregation sites tended to have higher soil penetrometer resistance values than in other locations within pasture field because of the frequent concentration of cattle around the different cattle congregation sites. Soil penetrometer resistance decreases linearly with distance away from the center of mineral feeders and water troughs; however, soil penetrometer resistance at the shaded areas was showing slight increase with distance away from the center. The least soil penetrometer resistance in all years were observed from shaded areas $\left(1200 \times 10^{3} \mathrm{~Pa}\right)$ while soil penetrometer resistance at water troughs was about $1600 \times 10^{3} \mathrm{~Pa}$ and at mineral feeders of $1800 \times 10^{3} \mathrm{~Pa}$. These values were in the "fair" range of root penetration. Penetrometer resistance of soils can be a good predictor of root system performance and especially useful in predicting root extension into the deeper regions of the root zone at the congregation zone and grazing zone in pasture.
\end{abstract}

beef cattle / congregation sites / sustainability / agriculture / forage-based pastures

\section{INTRODUCTION}

Grazing animals have dominant effects on the movement and utilization of nutrients through the soil and plant system, and thus on the fertility of pasture soils (Sigua and Coleman, 2007; Haynes and Williams, 1993; Haynes, 1981). Grazing can accelerate and alter the timing of nutrient transfers, and increase the amount of nutrients cycled from plant to soil (Klemmendson and Tiedemann, 1995). Franzluebbers et al. (2000) reported that over long periods, the position of shade and water sources for grazing cattle could influence the spatial distribution of soil biochemical properties including soil organic carbon and nitrogen, particulate organic carbon and nitrogen, microbial biomass, and net nitrogen mineralization. Thrash (1997) measured soil particle size distribution and infiltration of water into the soil along transects radiating from drinking troughs in the Kruger National Park, South Africa. He reported that concentration of large herbivores around the troughs was causing negative impacts on the infiltration rate of

* Corresponding author: gilbert.sigua@ars.usda.gov the soils, with implications for the rate of soil loss and the soil moisture regime.

Elsewhere, grazing, trampling, and dung deposition by large herbivores often result in a zone of impact on many vegetation and soil parameters including herbaceous vegetation basal cover, soil bulk density, and penetrability that decreases as distance increases away from water points (Thrash et al., 1991; Andrew and Lange, 1986). The effect of trampling appears to be less severe on vegetated grasslands than on poor or bare soil (Warren et al., 1986). Other effect of trampling is on breaking soil aggregates. Homogenization of soil by breaking soil aggregates is known to cause a flush of $\mathrm{C}$ mineralization that is likely due to release of organic matter protected within aggregates (Elliot, 1986; Powlson, 1980).

Understanding cattle movement in pasture situations is critical to understanding their impact on agro-ecosystems' integrity and sustainability. Movement of free-ranging cattle varies due to spatial arrangement of forage resources within pastures (Senft et al., 1985) and the proximity of water (Holechek, 1988; Ganskopp, 2001), mineral feeders (Martin 
Table I. Selected properties of surface soil $(0-25 \mathrm{~cm})$ averaged within respective beef cattle pasture field in Brooksville, FL, USA.

\begin{tabular}{lccc}
\hline Property & $\begin{array}{c}\text { Main station } \\
\left(28.60-28.63^{\circ} \mathrm{N} ;\right.\end{array}$ & $\begin{array}{c}\text { Turnley unit } \\
\left(28.58-28.62^{\circ} \mathrm{N} ;\right.\end{array}$ & Average \\
& $\left.82.36-82.38^{\circ} \mathrm{W}\right)$ & $\left.82.26-82.29^{\circ} \mathrm{W}\right)$ & \\
\hline Texture, $\mathrm{g} \mathrm{kg}^{-1}$ & & & \\
Sand & 750 & 825 & 787.5 \\
Silt & 200 & 125 & 162.5 \\
Clay & 50 & 50 & 50.0 \\
Bulk density $\left(\mathrm{g} \mathrm{cm}^{-3}\right)$ & 1.65 & 1.46 & 1.56 \\
pH in water & 6.27 & 6.38 & 6.32 \\
Calcium, $\mathrm{mg} \mathrm{kg}^{-1}$ & 1145.3 & 602.9 & 874.1 \\
Magnesium, $\mathrm{mg} \mathrm{kg}^{-1}$ & 97.9 & 88.8 & 93.4 \\
Potassium, mg kg-1 & 79.0 & 48.0 & 63.4 \\
Soil organic C, $\mathrm{g} \mathrm{kg}^{-1}$ & 3.4 & 3.5 & 3.45 \\
\hline
\end{tabular}

and Ward, 1973), and shades to grazing sites. Hammond and Olson (1994) and Bowers et al. (1995) reported that temperate British breeds (Angus and Hereford) of Bos taurus cows grazed less during the day than tropically adapted Senepol cows, but compensated for reduced grazing activity during the hotter parts of the day by increasing time spent grazing at night. Grazing animals congregate close to the shade and watering areas during the warmer periods of the day (Mathews et al., 1994, 1999). White et al. (2001) reported that there was a correlation between time spent in a particular area and the number of excretions and this behavior could lead to an increase in the concentration of soil nutrients close to shade and water. We hypothesized that cattle congregation sites may have higher soil penetrometer resistance than in other pasture locations under subtropical conditions. To verify our hypothesis, we tested whether cattle congregation sites typical on most forage-based cow-calf ranches, such as mineral feeders, water troughs, and shade areas are more compacted and have greater soil penetrometer resistance than in other pasture locations under Florida conditions.

\section{MATERIALS AND METHODS}

\subsection{Study site}

The Subtropical Agricultural Research Station is a cooperative research unit of the United States Department of Agriculture-Agricultural Research Service and the University of Florida and is located seven miles north of Brooksville, FL. The station has three major pasture units with combined total area of about 1538 ha with 1295 ha in permanent pastures. Cattle used for nutritional, reproductive, and genetic research on the station include about 500 head of breeding females with a total inventory of about 1000 head of cows, calves, and bulls. Most of the soils at the study sites were described as welldrained, Candler fine sand, uncoated hyperthermic family of the Typic Quartzipssaments. Forage production potential of the soils in the station is generally low to medium; the main limitation being droughtiness.

Table I shows some of the selected properties of surface $(0-25 \mathrm{~cm})$ soils in the study sites. The average annual pre- cipitation in the station was about $1262 \mathrm{~mm}$ with approximately half of this amount occurring during mid-June through mid-September. The lowest average temperature of $14{ }^{\circ} \mathrm{C} \mathrm{oc}-$ curs during January, but frosts are frequent during the winter months. The highest average temperature occurs during August although highs in the mid- $30{ }^{\circ} \mathrm{C}$ range occur regularly from May through September.

Cattle production at the station is forage based with the tropical grass, bahiagrass (Paspalum notatum, Flügge), the predominant forage species (1 295 ha). Most of the bahiagrass pastures have been established for over 30 years. The other major forage species (255 ha) is rhizoma peanuts (Arachis glabrata, Benth), a tropical legume with forage quality similar to alfalfa (Medicago sativa). Rhizoma peanut pastures are not pure stands of legume, but are mixtures with bahiagrass and bermudagrass (Cynodon dactylon). Most of the rhizoma peanuts stands were planted between 1980 and 1990.

\subsection{Pasture management and fertilization}

At the beginning of 1990, bahiagrass pastures were fertilized in the spring with $76.5 \mathrm{~kg} \mathrm{~N}, 9.8 \mathrm{~kg} \mathrm{P}$, and $37.4 \mathrm{~kg} \mathrm{~K} \mathrm{ha}^{-1}$ based on the revised fertilizer recommendation suggested by Chambliss (1999). Historically, grazing cattle were rotated among pastures to allow rest periods of $2-4$ wk based on herbage mass. The timing of movement for rotationally grazed cattle was determined by the herd manager's perception of forage availability based on plant height and not based on pasture measurement (Williams and Hammond, 1999). Starting in 2000 , cattle were rotated on a 3-d grazing interval with 24 days of rest between pastures. For this study, the average number of grazing cattle (cow-calf) was about 44 heads with grazing days of about 5.4 on a monthly basis. In general, all pastures were grazed during the spring of the year when normal drought conditions limit forage production. After the start of summer rainy season, pastures that were to be hayed were dropped out of the grazing cycle (usually starting in July) and forage growth allowed to accumulate for hay production. Pastures were managed for grazing in the spring until July followed by haying in late summer/early fall of each year.

\subsection{Soil penetrometer resistance test}

Soil penetrometer resistance around the congregations sites (mineral feeders, $\mathrm{n}=3$; water troughs, $\mathrm{n}=3$; and shaded areas, $\mathrm{n}=3$ ) in established ( $>10 \mathrm{yr}$ ), grazed beef cattle pastures were collected in the fall and spring of 2004, 2005, and 2006, respectively. Soil penetrometer readings were taken at two soil depths $(0-20 \mathrm{~cm}$ and $20-40 \mathrm{~cm}$ ) following radial (every 90 degrees) sampling patterns at $0.9,1.7,3.3,6.7,13.3,26.7$, and $53.3 \mathrm{~m}$ from the approximate center of mineral feeders, water troughs and shaded areas (Fig. 1).

Measurements of soil penetrometer resistance were taken during spring and fall in $2004(\mathrm{n}=950), 2005(\mathrm{n}=948)$, and $2006(\mathrm{n}=950)$ using the Dickey-John Penetrometer (Dickey-John Corp). Soil samples were also taken from each site of measurement for moisture content determination 


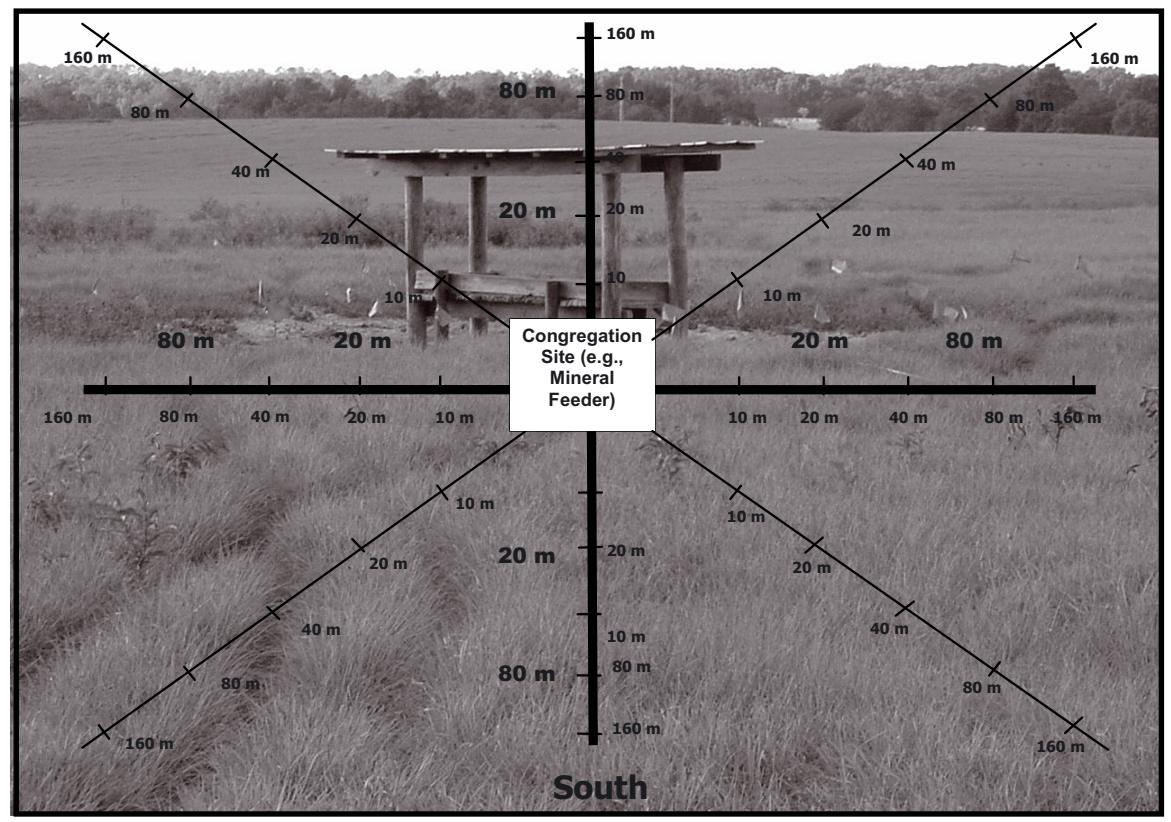

Figure 1. Sampling location and sampling scheme following radial (every 90 degrees: north, south, east, and west direction) patterns at 0.9 , 1.7, 3.3, 6.7, 13.3, 26.7 and 53.3 m away from the approximate center of mineral feeders, water troughs and shaded areas in Brooksville, FL, USA.

(Gravimetric Method). The soil penetrometer is designed to mimic a plant root, which consists of a 30-degree circular stainless steel cone with a driving shaft and pressure gauge. This penetrometer comes with two cones, one with a base diameter of $2.03 \mathrm{~cm}$ for soft soils and $1.28 \mathrm{~cm}$ for hard soils (Fig. 2). The driving shaft is graduated every $7.62 \mathrm{~cm}$ (3 inches) to allow determination of depth of compaction. The pressure readings are in pounds per square inch (psi). Pressure readings were converted to Pascal unit by multiplying psi values with $6.9 \times 10^{3}$. The unit of pressure reported on this paper is in Pascal.

\subsection{Statistical analysis}

Soil penetrometer resistance data were analyzed using the PROC MIXED procedures (SAS Institute, 2000). The model included congregation sites, sampling position, distance away from the center of congregation sites, soil depth, and their interactions as fixed effects and replicate as random effect. The pooled data (2004, 2005 and 2006) were tested initially for normality (SAS Institute, 2000). Where the F-test indicated a significant $(P \leq 0.05)$ effect, means were separated following the procedures of Duncan Multiple Range Test (DMRT).

\section{RESULTS AND DISCUSSION}

Our results supported our hypothesis that cattle congregation sites had higher soil penetrometer resistance than in other pasture locations. Soil penetrometer resistance varied significantly with cattle congregation sites $(P \leq 0.001)$; distance away from the center of cattle congregation sites $(P \leq 0.001)$, sampling depth $(P \leq 0.001)$ and the interaction of cattle congregation sites and distance away from the center of cattle congregation sites $(P \leq 0.001$; Tab. II). These results suggest that water troughs $\left(1706 \pm 656 \times 10^{3} \mathrm{~Pa}\right)$ has the greatest soil penetrometer resistance (averaged across distance away from the center of cattle congregation sites) followed by mineral feeders $\left(1668 \pm 685 \times 10^{3} \mathrm{~Pa}\right)$. The shaded areas $(1332 \pm 695 \times$ $10^{3} \mathrm{~Pa}$ ) had the least soil penetrometer resistance (Fig. 3). Concentration of cattle around the mineral feeders and water troughs was causing negative impacts on the infiltration rate of the soils and soil moisture levels, with implications for the degree of soil penetrometer resistance. Soils around the mineral feeders $\left(36 \pm 3 \mathrm{~g} \mathrm{~kg}^{-1}\right)$ and water troughs $\left(42.9 \pm 8.2 \mathrm{~g} \mathrm{~kg}^{-1}\right)$ are much drier than the soils around the shaded areas $(57 \pm$ $3 \mathrm{~g} \mathrm{~kg}^{-1}$ ). Drier soils at the mineral feeders and water troughs tended to be harder and more compacted than moist soils at the shaded areas (Tab. III).

Soil penetrometer resistance decreases linearly with distance away from the center of mineral feeders $(-119.5 \mathrm{x}+$ $\left.2136.9 ; R^{2}=0.85^{* *}\right)$ and water troughs $(-112.8 \mathrm{x}+2095.4$; $\left.R^{2}=0.94 * *\right)$; however, soil penetrometer resistance at the shaded areas $\left(25.6 \mathrm{x}+1230.8 ; R^{2}=0.77 * *\right)$ was showing slight increase with distance away from the center (Figs. 4 and 5). The interaction effects of cattle congregation sites and year on soil penetrometer resistance were also significant (Tab. II). The greatest penetrometer resistance of soils was observed in 2006 with mean soil penetrometer resistance of $2011 \times 10^{3} \mathrm{~Pa}, 1916 \times 10^{3} \mathrm{~Pa}$ and $2103 \times 10^{3} \mathrm{~Pa}$ for mineral feeders, shaded areas and water troughs, respectively. The average soil penetrometer resistance in 2004, 2005 and 2006 were $1234 \times 10^{3} \mathrm{~Pa}, 1275 \times 10^{3} \mathrm{~Pa}$ and $2011 \times 10^{3} \mathrm{~Pa}$, respectively (Tab. III). These values when compared with threshold numbers shown in Figure 6 would be within the "good" to "fair" range, thus having high to moderate degree of root penetration for bahiagrass in pasture with cow-calf operation. Root penetration decreases linearly with penetration 


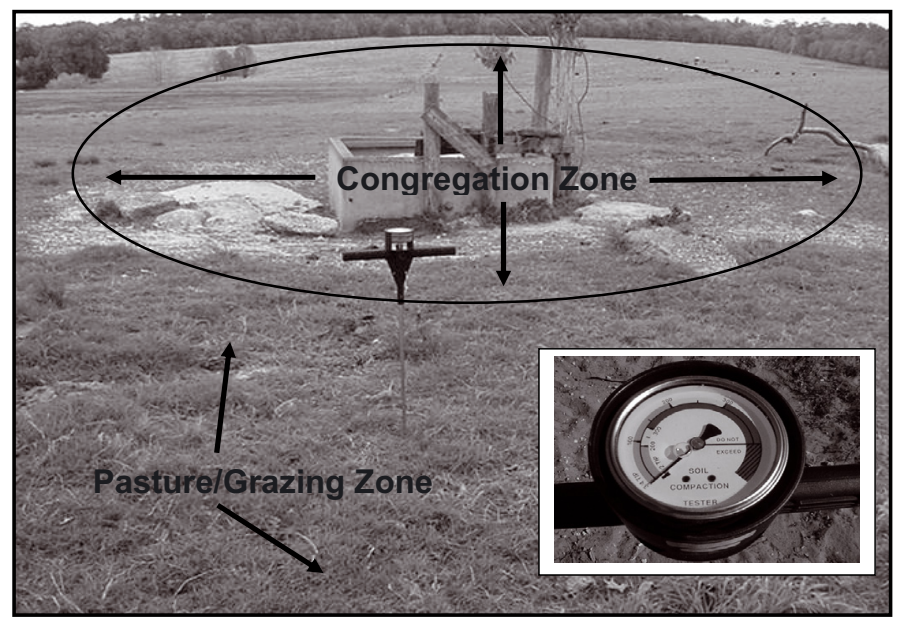

Figure 2. Taking measurements at congregation zone and pasture zone using a hand-held cone penetrometer (Dickey-John Corp).

Table II. Analysis of variance (F values) on soil penetrometer resistance in forage-based cow-calf congregation sites.

\begin{tabular}{lc}
\hline $\begin{array}{l}\text { Sources of } \\
\text { variations }\end{array}$ & $\begin{array}{c}\text { Soil penetrometer } \\
\text { resistance }\end{array}$ \\
\hline Among congregation sites (CCS) & $123.22^{* * *}$ \\
Among sampling position (SP) & $\mathrm{ns}$ \\
Among year of sampling (Y) & $582.41^{* * *}$ \\
Distance away from the center (DC) & $23.63^{* * *}$ \\
Soil depth (SD) & $22.06^{* * *}$ \\
CCS $\times$ DC & $13.79^{* * *}$ \\
CCS $\times$ SD & $\mathrm{ns}$ \\
CCS $\times$ Y & $18.08^{* *}$ \\
\hline
\end{tabular}

$* * * P \leq 0.001 ; * * P \leq 0.01 ; * P \leq 0.05 ; \mathrm{ns}-$ not significant.

resistance, until almost no roots penetrate into soil with penetration resistance of between $2500 \times 10^{3} \mathrm{~Pa}$ and $3000 \times$ $10^{3} \mathrm{~Pa}$ (Fig. 6). These higher values of soil penetrometer resistance may impede the movement of water and air through the soil by reducing the number of large pores. The impeded aeration that results can inhibit root growth (Hillel, 1982). The cone penetrometer (Fig. 2) looks promising as a tool for predicting root system performance and can be best described by a quadratic equation: Root penetration $(\%)=153.1+4.8 \mathrm{x}^{2}-$ $55.2 \mathrm{x} ; R^{2}=0.98^{* *} ; \mathrm{x}$ is the soil penetrometer resistance reading (Fig. 6).

Our cattle congregation sites, especially mineral feeders and water troughs have higher soil penetrometer resistance readings when compared with values of soil penetrometer resistance at some distance away from the center. Combination of grazing and trampling near the center $(0.9$ to $1.7 \mathrm{~m})$ of cattle congregation sites have reduced the density of grass cover, followed with increased bulk density, diminished infiltration and could have increased runoff at higher elevations resulting from compaction of soil by cattle. Other researchers (Hofmann and Ries, 1988; Nielsen and Hole, 1964; Reed and Peterson, 1961) reported similar results. Areas around our cattle congregation sites $(0.9$ to $1.7 \mathrm{~m})$ may have reduced soil aggregate stability, with surface becomes crusted which can be correlated to bare soil and higher soil bulk density. Similarly, Orodho et al.
(1990) reported that heavy grazing caused an $8 \%$ increase in soil bulk density ( 1.4 to $1.5 \mathrm{~g} \mathrm{~cm}^{-3}$ ) in sandy loam. Once a soil is compacted, the bulk density and the strength of the soil are increased.

Intensive cattle trampling that we observed from areas around cattle congregation sites, especially within the congregation zone may help to explain why penetrometer resistance in soils were high as we anticipated. The effect of trampling appears to be less severe on vegetated pasture than on poor or bare soil (Warren et al., 1986). Scholefield and Hall (1986) calculated that a $530 \mathrm{~kg}$ cow would exert $250 \mathrm{kPa}$ of vertical stress while walking on level ground. Decreases in soil pore size can restrict the rooting of grass, inhibit air, and water movement (Scholefield and Hall, 1985), which makes the grass cover more vulnerable to further damage by cattle trampling. Moderation of stocking rations is probably an effective means of decreasing poaching generally, and is beneficial to both grass and animal production (Hofmann and Ries, 1988). Heathwaite et al. (1990) stressed the need to decrease animal numbers to avoid poaching around watering points. Elsewhere, grazing, trampling, and dung deposition by large herbivores often result in a zone of impact on many vegetation and soil parameters including herbaceous vegetation basal cover, soil bulk density, and penetrability (Thrash, 1997; Thrash et al., 1991; Andrew and Lange, 1986).

Our results support the idea that the area around or near cattle congregation sites would tend to have higher soil penetrometer resistance values than in other locations within pasture field because of the frequent concentration of cattle around the different cattle congregation sites. Higher degree of soil penetrometer resistance within our cattle congregation sites had led to destruction of a large portion of aerial system, stolons and roots, followed by removal of vegetation cover resulting in at least $50 \%$ bare surface (Fig. 2). Removal of vegetations or grass at or near the center of cattle congregation sites can reduce soil fertility, soil organic matter content and soil organic carbon. The bare soil within the vicinity $(0.9$ to $1.7 \mathrm{~m})$ of mineral feeders and water troughs and the frequent visit by grazing animals for mineral feeds, salts and water may explained 


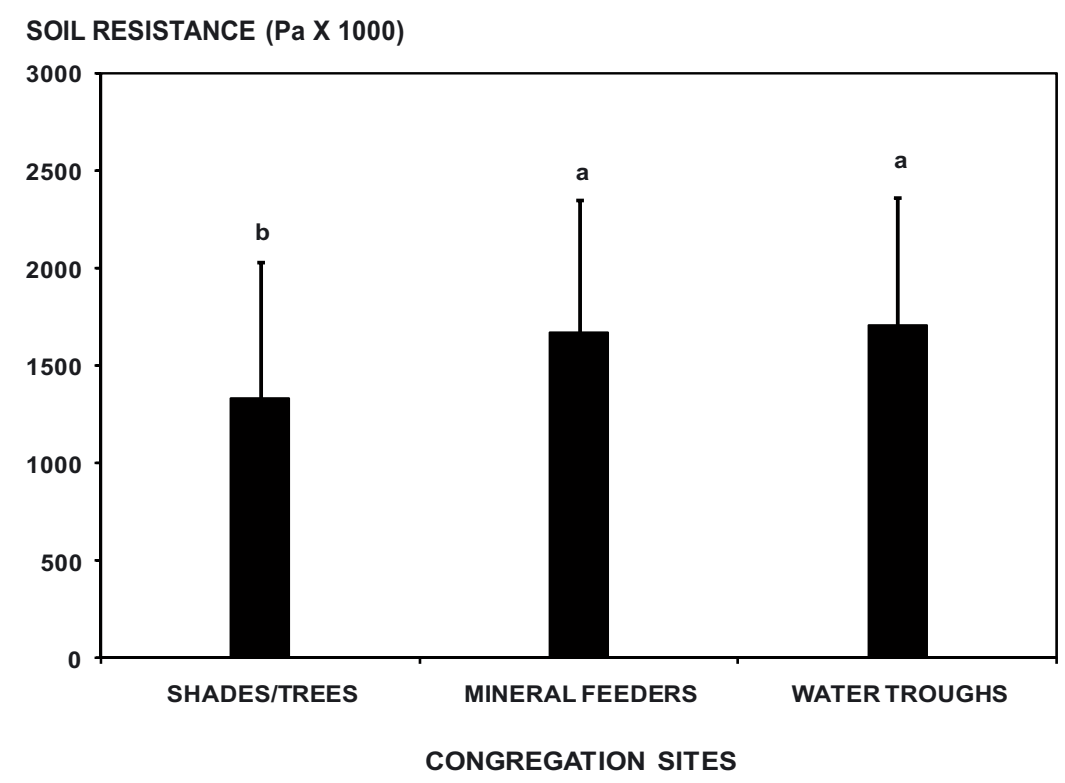

Figure 3. Mean comparison of soil penetrometer resistance among the different cattle congregation sites. Means of soil penetrometer resistance are significantly different $(P \leq 0.05)$ when superscripts ( $\mathrm{a}$ or $\mathrm{b})$ located at top bars are different.

Table III. Soil penetrometer resistance and moisture content of soils (mean \pm standard error) among the different congregation sites within pastures with cow-calf operations as affected by sampling direction, distance away from the congregation sites and soil sampling depth from 2004 to 2006.

\begin{tabular}{lcc}
\hline $\begin{array}{l}\text { Landscape } \\
\text { properties }\end{array}$ & $\begin{array}{r}\text { Soil penetrometer resistance } \\
(\text { Pascal; } \times 1000)\end{array}$ & $\begin{array}{c}\text { Moisture content } \\
\left(\mathrm{g} \mathrm{kg}^{-1}\right)\end{array}$ \\
\hline 1. Congregation sites $(\mathrm{n}=810)$ & $1667.6 \pm 22.9 \mathrm{a}^{\dagger}$ & $36.3 \pm 2.9 \mathrm{~b}$ \\
a. Mineral Feeders & $1705.8 \pm 24.3 \mathrm{a}$ & $42.9 \pm 8.2 \mathrm{~b}$ \\
b. Water Troughs & $1332.9 \pm 23.9 \mathrm{~b}$ & $56.7 \pm 2.9 \mathrm{a}$ \\
c. Shaded Areas & & \\
\hline 2. Sampling position $(\mathrm{n}=600)$ & $1539.1 \pm 28.5 \mathrm{a}$ & $41.6 \pm 7.6 \mathrm{a}$ \\
a. East & $1564.2 \pm 27.8 \mathrm{a}$ & $48.1 \pm 13.4 \mathrm{a}$ \\
b. North & $1563.9 \pm 29.3 \mathrm{a}$ & $45.2 \pm 5.6 \mathrm{a}$ \\
c. South & $1578.4 \pm 28.7 \mathrm{a}$ & $47.2 \pm 7.5 \mathrm{a}$ \\
d. West & & \\
\hline 3. Distance $(\mathrm{m})(\mathrm{n}=360)$ & $1779.4 \pm 39.9 \mathrm{a}$ & $36.3 \pm 4.5 \mathrm{~b}$ \\
a. 0.9 & $1670.8 \pm 34.4 \mathrm{~b}$ & $34.5 \pm 4.8 \mathrm{~b}$ \\
b. 1.7 & $1656.5 \pm 39.9 \mathrm{~b}$ & $29.4 \pm 1.8 \mathrm{c}$ \\
c. 3.3 & $1483.5 \pm 39.2 \mathrm{c}$ & $47.8 \pm 3.6 \mathrm{~b}$ \\
d. 6.7 & $1431.4 \pm 38.3 \mathrm{c}$ & $50.7 \pm 7.6 \mathrm{~b}$ \\
e. 13.3 & $1426.6 \pm 38.4 \mathrm{c}$ & $67.7 \pm 8.4 \mathrm{a}$ \\
f. 26.7 & $1424.9 \pm 38.7 \mathrm{c}$ & $77.8 \pm 5.8 \mathrm{a}$ \\
g. 53.3 & & \\
4. Time $($ Year $)(\mathrm{n}=945)$ & $1234.1 \pm 18.9 \mathrm{~b}$ & $50.4 \pm 1.8 \mathrm{~b}$ \\
a. 2004 & $1275.1 \pm 19.8 \mathrm{~b}$ & $69.9 \pm 4.5 \mathrm{a}$ \\
b. 2005 & $2011.7 \pm 18.9 \mathrm{a}$ & $50.4 \pm 1.4 \mathrm{~b}$ \\
c. 2006 & & \\
5. Soil depth $(\mathrm{cm})(\mathrm{n}=1189)$ & $1510.1 \pm 19.8 \mathrm{~b}$ & $38.9 \pm 2.9 \mathrm{~b}$ \\
a. $0-20$ & $1612.1 \pm 20.7 \mathrm{a}$ & \\
b. $20-40$ & & \\
\hline
\end{tabular}

\footnotetext{
${ }^{\dagger}$ Means in column under each sub-heading followed by same letter(s) are not significantly different from each other at $P \leq 0.05$.
} 


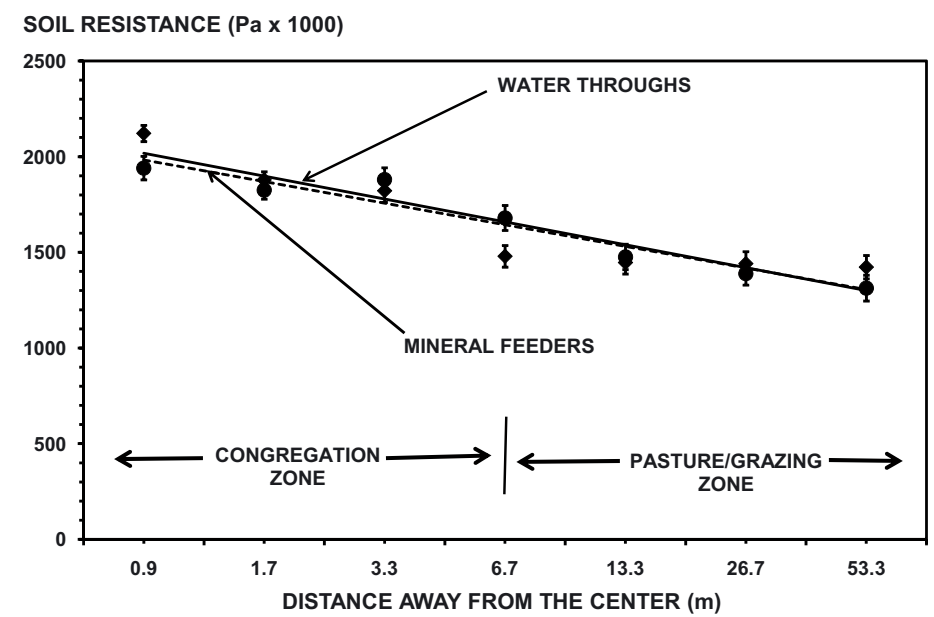

Figure 4. Regression analysis showing the relationship of soil penetrometer resistance with distance away from the center of the different congregation sites (solid line: water troughs $=-112.8 \mathrm{x}+2095.4 ; R^{2}=0.94 * *$; dash line: mineral feeders $=-119.5 \mathrm{x}+2136.9 ; R^{2}=0.85^{* *}$ ).

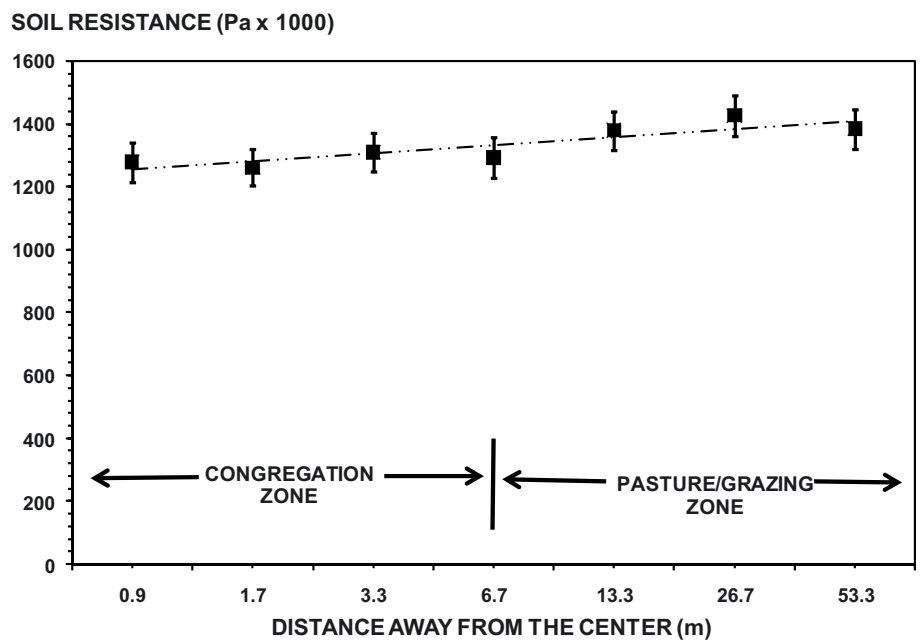

Figure 5. Regression analysis showing the relationship of soil penetrometer resistance with distance away from the center of shaded areas $\left(25.6 \mathrm{x}+1230.8 ; R^{2}=0.77 * *\right)$.

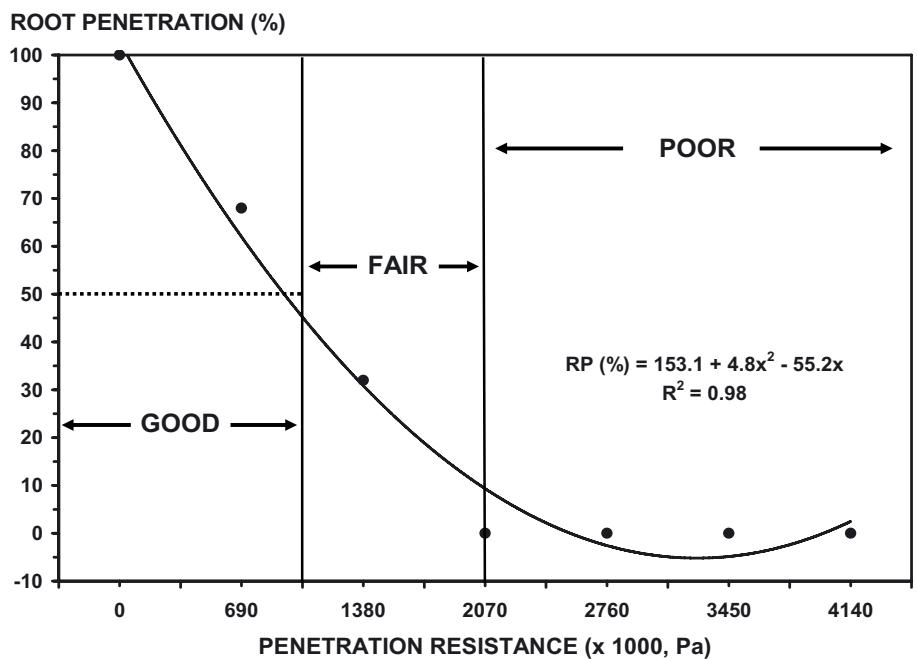

Figure 6. Relationship of root penetration $(\%)$ and soil penetrometer resistance (Pa) using hand-held penetrometer (Good root penetration: $0-1,035 \times 1000 \mathrm{~Pa}$; Fair root penetration: $1,035 \times 1000 \mathrm{~Pa}-2,070 \times 1000 \mathrm{~Pa}$; Poor root penetration: $>2070 \times 1000 \mathrm{~Pa}$ ). 
why cattle congregation sites have higher bulk density and soil penetrometer resistance readings when compared with other locations in the pasture.

\section{CONCLUSIONS}

Concentration of large herbivores around the mineral feeders and water troughs was causing negative impacts on the infiltration rate of the soils and soil moisture levels, with implications for the degree of soil penetrometer resistance. Visual observations supported the idea that soils around the mineral feeders and water troughs were much drier than the soils around the shaded areas. Drier soils at the mineral feeders and water troughs tended to be harder and more compacted than moist soils at the shaded areas. Soil penetrometer resistance decreases linearly with distance away from the center of mineral feeders and water troughs. The least soil penetrometer resistance in all years were observed from shaded areas $\left(1200 \times 10^{3} \mathrm{~Pa}\right)$ while soil penetrometer resistance at water troughs was about $1600 \times 10^{3} \mathrm{~Pa}$ and at mineral feeders of $1800 \times 10^{3} \mathrm{~Pa}$. These values were in the "fair" range of root penetration.

Our results support the idea that the area around or near cattle congregation sites would tend to have higher soil penetrometer resistance values than in other locations within pasture field because of the frequent concentration of cattle around the different cattle congregation sites. Moderation of stocking rations is probably an effective means of decreasing poaching generally, and is beneficial to both grass and animal production. Because penetrometer resistance data can be collected and analyzed more quickly, easily and economically than bulk density data, it might be more useful. Ranchers may consider using movable mineral feeders and water troughs in their pasture so they can move them around within pasture, thus avoiding soil compaction at or near cattle congregation sites. Penetrometer resistance of soils can be a good predictor of root system performance and especially useful in predicting root extension into the deeper regions of the root zone at the congregation and grazing zone in pasture. Further research is continuing, including sampling at cattle congregation sites from other region of Florida.

\section{REFERENCES}

Andrew M.H., Lange R.T. (1986) Development of a new piosphere in arid chenopod shrubland grazed by sheep. (1) Changes to the soil surface, Aust. J. Ecol. 3, 336-339.

Bowers E.J., Hammond A.C., Chase C.C. Jr., Olson T.A. (1995) Effect of breed on indicators of heat tolerance and grazing activity in lactating Angus and Brahman cows in Florida, J. Anim. Sci. 73, 131.

Chambliss C.G. (1999) Florida Forage Handbook, Univ. Florida Coop. Ext. Serv. SP253.

Elliott ET. (1986) Aggregate structure and carbon, nitrogen and phosphorus in native and cultivated soils, Soil Sci. Soc. Am. J. 50, 627-633.

Franzluebbers A.J., Stuedemann J.A., Schomberg H.H. (2000) Spatial distribution of soil carbon and nitrogen pools under grazed tall fescue, Soil Sci. Soc. Am. J. 64, 635-639.

Ganskopp D. (2001) Manipulating cattle distribution with salt and water in large arid-land pastures: a GPS/GIS assessment, Appl. Anim. Behav. Sci. 73, 251-262.
Hammond A.C., Olson T.A. (1994) Rectal temperature and grazing time in selected beef cattle breeds under tropical summer conditions in subtropical Florida, Trop. Agr. (Trinidad) 71, 128-134.

Haynes R.J. (1981) Competitive aspects of the grass-legume association, Adv. Agron. 33, 227-261.

Haynes R.J., Williams P.H. (1993) Nutrient cycling and soil fertility in grazed pasture ecosystem, Adv. Agron. 49, 119-199.

Heathwaite A.L., Burt J.P., Troudgill S.T. (1990) Land use controls on sediment production in a lowland catchment, southwest England, in: Boardman J., Foster I.D.L., Dearing J.A. (Eds.), Soil Erosion on Agricultural Lands, J. Wiley, Chichester, pp. 69-86.

Hillel D. (1982) Fundamentals of soil physics, Academic Press, New York.

Hofmann L., Ries R.E. (1988) Vegetation and animal production from reclaimed mined land pastures, Agron. J. 80, 40-44.

Holechek J.L. (1988) An approach for setting stocking rate, Rangeland $10,10-14$.

Klemmendson J.O., Tiedemann A.R. (1995) Effects of nutrient stress, in: Bedunah D.J., Sosebee R. (Eds.), Wildland Plants: Physiological Ecology and Developmental Morphology, Society of Range Management, Denver, CO, pp. 414-439.

Martin S.C., Ward D.E. (1973) Salt and meal-salt help distribute cattle use on semi-desert range, J. Range Manage. 26, 94-97.

Mathews B.W., Tritschler J.P., Carpenter J.R., Sollenberger L.E. (1999) Soil macronutrients distribution in rotationally stocked kikuyugrass paddocks with short and long grazing periods, Commun. Soil Sci. Plant Anal. 30, 557-571.

Mathews B.W., Sollenberger L.E., Nair V.D., Staples C.R. (1994) Impact of grazing management on soil nitrogen, phosphorus, potassium, and sulfur distribution, J. Environ. Qual. 23, 1006-1013.

Nielsen G.A., Hole F.D. (1964) Earthworms and the development of coprogenous A1 horizons in forest soils of Wisconsin, Proc. Soil Sci. Soc. Am. 28, 426-430.

Orodho A.B., Trilica M.J., Bonham C.D. (1990) Long-term heavygrazing effects on soil and vegetation in the four corners region, Southwest Nat. 35, 9-14.

Powlson D.S. (1980) The effects of grinding on microbial and nonmicrobial organic matter in soil, J. Soil Sci. 31, 77-85.

Reed M.J., Peterson R.A. (1961) Vegetation, soil and cattle responses to grazing on northern Great Plains range, USDA Technical Bulletin 1252, U.S. Government Printing Office, Washington DC, 79 p.

SAS Institute. (2000) SAS/STAT User's Guide, Release 6.03, SAS Institute, Cary, North Carolina, $494 \mathrm{p}$.

Scholefield D., Hall D.M. (1985) Constricted growth of grass roots through rigid pores, Plant Soil 85, 153-162.

Scholefield D., Hall D.M. (1986) A recording penetrometer to measure the strength of soil in relation to the stresses exerted by a walking cow, J. Soil Sci. 37, 165-176.

Senft R.L., Rittenhouse L.R., Woodmanse R.G. (1985) Factors influencing patterns of cattle grazing behavior on shortgrass steppe, J. Range Manage. 38, 82-87.

Sigua G.C., Coleman S.W. (2007) Sustainable management of nutrients in forage-based pasture soils: effect of animal congregation sites, J. Soils Sediments 6, 249-253.

Thrash I. (1997) Infiltration rate of soil around drinking troughs in the Kruger National Park, South Africa, J. Arid Environ. 35, 617-625.

Thrash I., Nel P.J., Theron G.K., du Bothma J.P. (1991) The impact of water provision for game on the herbaceous vegetation basal cover around a dam in Kruger National Park, Koedoe 34, 121-130.

Warren S.D., Thurow T.L., Blackburn W.H., Garza N.E. (1986) The influence of livestock trampling under intensive rotation grazing on soil hydrologic characteristics, J. Range Manage. 39, 491-495.

White S.L., Sheffield R.E., Washburn S.P., King L.D., Green G.T. Jr. (2001) Spatial and time distribution of dairy cattle excreta in an intensive pasture system, J. Environ. Qual. 30, 2180-2187.

Williams M.J., Hammond A.C. (1999) Rotational vs. continuous intensive stocking management of bahiagrass pastures for cows and calves, Agron. J. 91, 11-16. 